\section{Scientists quiet in Japan}

SIR - You suggest in your special issue on "Science in Japan"' (Nature 29 September) that the answer to the "cry" for more creativity in Japan lies simply in substantial support of basic science in the universities (p.382). In 1972 you complained of the relative neglect of basic science by the Japanese Government (p.356); this year you indicate again that "more autonomy, more resources for research and more say in how they are used" remain as a remedy for the present state of universities in Japan. You are afraid that "tradition and the government's budget officers would be offended, but those would be small prices to pay for an overdue reform" (p.382).

Scientists in universities are a potential source of criticism of the policies of a very conservative government. By keeping the universities short of money in comparison with booming industry, and providing ample research grants to a selected few conformist scientists, the government could effectively control a possibly critical group of scientists while maintaining scientific activity at a reasonable level.

In such an ambience scientists have been rather easily tamed. By contrast, during the post-war period, Japanese scientists could be more independent of government control as illustrated by the early successful activities of the Japan Science Council (p.361); also during the 1960 s when large overseas research grants (mainly from the United States) were readily available for internationally active Japanese scientists. This last pattern was soon criticized, however, during the emergence of student power in the late sixties, which was followed by the "oil shock". Then the Japanese economy finally overtook Western rivals, leading to a perfect control of scientists by the government. Both the current detachment of scientists from the once popular Japan Science Council, and the lagging of Japanese biotechnology in spite of the presence of some active groups of molecular biologists (p.377) may be explained by this fact. In genetic engineering, Japanese scientists, as well as bureaucrats, did not like to stand out conspicuously in pushing controversial technology until the "dust had settled". Hence the initially very stringent Japanese guidelines for recombinant DNA were issued only in 1979 instead of 1976, though relaxed quickly afterwards. Public debate on scientific matters is not popular in Japan. I have not seen the "Erato" subjects (p.373) debated extensively in the scientific media, either before they received massive governmental support, or after. Certainly this is not the best way to encourage creativity among scientists and universities. This point is recognized as a dilemma for Japan's quest for creativity in Japan itself as well as in the United States (Keyworth, G.A., Science 217, 606-609; 1982).
The following facts would further corroborate my contention. For quite a few years staff members of the national universities, like all other employees of the government, have had to apply for governmental permission for all private travel overseas, including holidays. So far, no complaint has been filed from the university members. Unlike Japanese writers and medical professionals the governmentdependent Japanese scientists have so far not organized a body working for the cause of nuclear disarmament, while SANA (Scientists Against Nuclear Arms) membership scores nearly $1,000,340$, and more than 100 in the United Kingdom, Australia and New Zealand, respectively. That trend is worrying, because Japanese society now looks alarmingly like that preceding the Second World War when practically all the liberals were effectively silenced. Those who have memories of that period are now reaching retiring age in the leading national universities. Would a conservative government like to boost scientists in the Japanese universities with additional resources now? Powerful opposition parties could promise that, but there is not even one of those in Japan.

ATUHIRo SiBATANI

CSIRO Division of Molecular Biology, North Ryde (Sydney),

NSW 2113, Australia

\section{Homologyana}

SIR - You are not fond of phrases such as "B-cell lymphoma DNA sequence nonhomology" (Nature 6 October, p.477). In fact, the word homology itself has become the object of a considerable amount of abuse in the columns of Nature and of nearly all journals that deal with comparisons of polynucleotide or polypeptide sequences.

Molecular biology has taken over the term homology from biology. According to the biological - and the initial molecular-biological - meaning of the word, two structures are said to be homologous when their similarities are extensive enough for us to assume their derivation from a common ancestral structure. The concept of homology is therefore all-ornone. DNA sequences, RNA sequences and protein sequences are homologous or not. They cannot display strong or weak homology, just as no one can be said to be 65 per cent pregnant (an example furnished to me by Walter Fitch). These remarks do not apply to a special case: two informational macromolecules may be homologous over 65 per cent of their length when the remaining 35 per cent are of a different evolutionary origin.

If another Greek or Latin word were to be adopted in order properly to express the idea that molecular biologists have usually in mind when they speak of 65 per cent homology, it might be "isology", as proposed many years ago by Marcel Florkin. Meanwhile, why not use the ordinary word "similarity" or "matches"? Two polynucleotide or polypeptide chains can be said to show 65 per cent matches, or a 65 per cent similarity. Using an ordinary word correctly is more professional than using a professional word incorrectly.

Because poor usage becomes good usage as soon as it is generally accepted, advocates of good usage are born losers, unless they fight early and hard. In regard to fighting for a proper use of the term homology, the hour is late.

Journal of Molecular Evolution,

Linus Pauling Institute,

440 Page Mill Road,

Palo Alto, California 94306, USA

\section{Terminal guidance}

SIR - With reference to your leading article on 13 October (p.561), all the proposed new Western weapons will have the novel and dangerous property of terminal guidance: so this is a new step for the qualitative arms race. Cruise and Pershing II will be ten times as accurate as SS20s and far more effective for use as warfighting weapons, or in the case of Pershing II for a first strike.

An analogy from the history of the arms race is the development of MIRV missiles. Not only did this greatly increase the numbers of warheads but, since one missile could then theoretically destroy several on the ground, a disarming first strike became at least a conceivable strategy. Since the potential to retaliate is the basis of mutual deterrence, MIRVing actually decreased our security. Terminal guidance is the next step, the increased accuracy making the theoretical destruction an achievable goal.

ROBERT WALL

47 Conduit Road,

Bedford MK4U IEQ, UK

\section{Not fit}

SIR - I regret that I am unable to agree with Pirie's assessment (Nature 20 October, p.664) that American English is more rational than that written in England, at least on the evidence given. Pirie quotes Gould as writing "this view fit nicely with most nineteenth century concepts," and interprets this use as different from the English norm, which would require fits. A simpler interpretation of Gould's reported usage is that fit is the past of the verb to fit, not the third person present singular. Fit as a past form is given as a second choice in Webster's Third New International Dictionary, and agrees with American usage. Fit as a third person present singular is not standard in the United States, not even in California.

W.E. HAZEN

Biology Department,

San Diego State University,

San Diego, California 92182, USA 